\title{
RESPONSE OF DIFFERENT GENOTYPES OF BROILERS TO LYSINE SUPPLEMENTATION RAISED UNDER PRACTICAL CONDITION
}

\author{
B. Indarsih and M. H. Tamsil \\ Faculty of Animal Science, Mataram University, \\ Jalan Majapahit No 62 Mataram, NTB Indonesia \\ Corresponding E-mail: budiindarsih@gmail.com
}

Received April 22, 2012; Accepted May 24, 2012

\begin{abstract}
ABSTRAK
Penelitian ini dilakukan untuk mengevaluasi suplementasi lisine pada broiler komersial umur 4 sampai 42 hari. Percobaan faktorial dengan 2 strain (Arbor Acres dan Lohmann) yang dibedakan jantan dan betina sebanyak 450 ekor, kemudian ditimbang dan secara acak ditempatkan pada 60 kadang bambu ukuran $2 \mathrm{~m}^{2}$ dalam bangunan kandang terbuka. Starter komersial diberi lisin mono-HCL dengan level 0,$0 ; 0,5 ; 1,0 ; 1,5 ;$ dan 2,0 g/kg dari umur 4-21 hari, kemudian diberi pakan finisher komersial dari umur 22-42 hari. Konsumsi pakan dan pertambahan bobot badan diukur setiap minggu. Pada umur 43 hari, 4 ekor untuk setiap ulangan diambil sebagai sampel dan dipotong untuk mengukur parameter karkas. Hasil penelitian menunjukkan bahwa penambahan lisin pada ransum komersial meningkatkan berat karkas secara signifikan $(\mathrm{P}<0,05)$, dan cenderung meningkatkan daging dada serta menurunkan lemak abdominal. Strain Arbor Acres merespon dengan baik pada pakan dengan lisin yang rendah sedangkan strain Lohmann merespon lebih baik pada pakan dengan lisin tinggi.

Katakunci: lisin, broiler, strain, daging dada, lemak abdominal
\end{abstract}

\begin{abstract}
This study evaluated lysine supplementation of 4 to 42 day of age of two commercial broiler genotypes (Arbor Acres and Lohmann). Four hundred and fifty day-old chicks were sexed and randomly distributed into 60 bamboo pens each $2 \mathrm{~m}^{2}$. A starter commercial diet as a basal diet was supplemented with lysine mono-HCL in a $2 \times 2 \times 5$ factorial arrangement with lysine levels of $0.0,0.5$, $1.0,1.5$ and $2.0 \mathrm{~g} / \mathrm{kg}$ fed from 4-21 days of age, and then followed by a finisher diet fed from 22-42 days of age. Feed consumption, body weight gain and FCR were determined on weekly basis. On d 43 of experiment, 4 birds per each replicate were processed for carcass parameters. Results of the study revealed that lysine supplementation in a starter commercial diet increased significantly carcass weight $(\mathrm{P}<0.05$. Improved breast meat and lower abdominal fat were found in lysine supplementation. Arbor Acres broilers response more efficient in low lysine whilst Lohmann broilers were better in a higher level of lysine.
\end{abstract}

Keywords: Lysine, broiler, genotype, breast meat, abdominal fat

\section{INTRODUCTION}

Responses between and even within a single genotype to different nutrition vary widely. However, differences in nutritional needs were the main factor influencing differences in the carcass, resulting in differences in body composition (Moran, 1994). This leads to differences in nutritional needs for growth, where one genotype was different from others, especially its response to protein and amino acids (Leclercq et al., 1993; Sterling et al., 2006). Praharaj et al. (2002) studied the interaction between genotypes and dietary lysine content in commercial broiler chicks during the period posthatching to $42 \mathrm{~d}$ of age. There was a significant genotype by dietary lysine interaction for body weights at 14 and $28 \mathrm{~d}$ of age.

Labadan et al. (2001) found the estimated lysine requirement for breast muscle growth of the 0 - to 2 -wk-old broiler $(1.32 \pm 0.01 \%)$ is substantially higher than the NRC (1984) or NRC (1994) estimates. For fast-growing chickens, age and sex affected the genetic potential for protein deposition (Samadi and Liebert, 2006; Dozier et $a l ., 2009)$ and there was a variation of energy and 
protein requirements at different broilers (Cherry et al., 1978).

Referring to Bartov and Plavnik (1998) that the amino acid levels recommended by NRC $(1971,1987,1994)$ were less appropriate in some experimental circumstances. Therefore, some studies revealed the need to correct the proportion levels of crude protein to lysine (Harm and Russell, 1995; Labadan et al., 2001). This is due to the fact that the lysine requirement is higher than the NRC (1994) requirement measured with the experimental situation (Lehmann et al., 1996; Kerr et al., 1999; Rezaei et al., 2004; Aftab et al., 2007; Indarsih and Pym, 2010). Breast meat deposition can be optimized on feeding at a higher level of lysine in the starter and finisher diets than those recommended by NRC (1994) as studied by Rezaei et al. (2004).

Lysine is one of the limiting amino acids in modern broiler diets and its inclusion in the diet of the several studies is intended to achieve optimal performance (Hosseini et al., 2009; Viola et al., 2009; Nasr and Kheiri, 2011) particularly for breast muscle growth (Moran and Bilgili, 1990; Labadan et al., 2001; Queentin et al., 2005). However, under the practical condition, efforts to maximize performance are impeded by insufficient supply of amino acids when the nutritional need for each genotype is not completely identified. In addition, most studies examined responses of broilers to lysine or amino acid requirements used the formulated diets based on the experimental condition (Labadan et al., 2001; Praharaj et al., 2002; Sterling et al., 2006). Therefore, the following study was conducted to determine the response of different commercial broilers to lysine supplementation. And the specific objective of this work is to examine a standard commercial ration in terms of its applicability for broiler industry under practical condition.

\section{MATERIALS AND METHODS}

\section{Birds and housing}

Four hundred and fifty day-old chicks of commercial broilers obtained from two national commercial breeding companies were used in this study. These two commercial genotypes (strain 1 $=$ Arbor Acres $=$ AA; strain $2=$ Lohmann $=\mathrm{LN}$ ) were obtained on the same day $(n=225$ per genotype) and they were then wing banded and sexed by feather sexing. The birds were randomly distributed into 60 bamboo cages of $1 \mathrm{~m}^{2}$ each and were equipped with one hanging feeder and one rounded plastic drinker. A standard commercial diet was offered for the first 3-days of age, and then they were fed an experimental diet supplemented by lysine until 42 day of age. Birds were provided 24 hours of light was throughout the experimental period. Chicks were vaccinated at the hatchery for Marek's disease while Newcastle Disease vaccination was carried out during the study. Experimental diets were provided in crumble form for starter phase and pellet form for finisher phase. The birds were kept in an open-sided house with uncontrolled temperature or varied. Feed and water were available ad libitum. Environmental temperature was recorded daily.

\section{Diets and Treatments}

The experiment was in a completely randomized design (CRD) in a factorial arrangement. Two genotypes, five dietary treatments and two sexes were imposed in this study. The birds were divided into five groups with three replicates each 12 birds (180 birds/ genotype), and fed a commercial starter diet containing $213 \mathrm{~g} \mathrm{CP} / \mathrm{kg}$ diet from d-old-chicks to 3 weeks of age, and then a commercial finisher diet containing $171 \mathrm{~g} \mathrm{CP} / \mathrm{kg}$ diet as a control group. Prior to study, feed were analyzed for crude protein, crude fat, and crude fiber (Table 1) according to the methods of the Association of Analytical Chemists (AOAC, 1990). The experimental diets were a commercial starter diet and supplemented with of $0.00,0.5,1.0,1.5$, and $2.0 \mathrm{~g} / \mathrm{kg}$ lysine mono-HCL. Rice hulls were finely grounded to provide $1.0 \%$ of the amount of a finisher diet that serves as a dilution.

\section{Measurement}

Individual body weight of broilers was recorded at the beginning of the experiment and at $9,16,23,30,37$ and 42 days of age thereafter. Feed conversion ratio (FCR) was calculated as the ratio between feed intake (FI) and body weight gain (BWG) taking into account in the calculation of dead chickens. Breast meat was measured by taking the breast meat to the left and right with the skinless and boneless. Abdominal fat was defined as fat around the abdomen, around vent and covering the gizzard.

At the end of the experiment on day 42, 4 broilers whose body weights were similar to the 
Table 1. Chemical Composition of Commercial Diets Used (\%)

\begin{tabular}{lcc}
\hline & Starter Diet & Grower Diets \\
\hline Crude Protein* & 21.3 & 17.1 \\
Crude Fiber & 3.4 & 3.7 \\
Crude Fat & 3.5 & 5.5 \\
Water & 12.2 & 11.7 \\
Ash & 10.7 & 10.9 \\
Calcium** & 0.9 & 0.8 \\
Phosphor & 0.7 & 0.6 \\
\hline
\end{tabular}

* Analyzed according to AOAC (1976)

** Information of manufacture

group average were selected from each of the replicate groups in each treatment. After a 12-h fast, birds were stunned with a knife, bled by severing the jugular vein, scalded in water for 1$1.5 \mathrm{~min}$, and defeathered manually to determine percentage breast meat (BM) and abdominal fat (AF).

\section{Data Analysis}

Data were analyzed by ANOVA based on the General Linear Model (GLM) procedure using SAS version 6:21 (SAS Institute Inc., 1985). Genotype, sex and lysine were as main effects. When differences among means were found, means were compared using Duncan's new multiple range test (Steel and Torrie, 1980 ).

\section{RESULTS AND DISCUSSION}

\section{Performance}

Body weight gain, feed intake, feed conversion and final body weight of two different genotypes from hatching until the age of 42 days were presented in Table 2. Figure 1 and 2 are graphs of body weight gain $(\mathrm{g} / \mathrm{d})$ of each commercial broiler chicken in response to lysine supplied diet which were measured weekly.

This study demonstrated that increasing dietary lysine have no significant effects on all growth performance parameters measured. However, significant differences in FI, FCR and BW but not BWG due to genotypes were observed (Table 2). Genotype by dietary lysine interaction was not significant at $42 \mathrm{~d}$ of age for
BWG, FI, FCR and BW. In terms of BWG, male broilers have a greater response than female broilers to dietary lysine (Table 2 and 4 ) as expected. However, FCR for both sexes was not significant $(\mathrm{P}>0.05)$. This indicates that males required a higher level of dietary lysine than females for maximal BWG and dietary digestible lysine for FCR was higher than for BWG (Greenwood et al., 2005; Dozier et al., 2009; Dozier et al., 2010; Indarsih and Pym, 2010; Mehri et al., 2010). Male growing chickens gained faster than females due to higher daily feed intake in males (Samadi and Libiert, 2006) were also observed in this study.

In general, broilers fed with a standard commercial diet showed lower BW, providing evidence that lysine supplementation is essential to improve performance. This study found that the $2.0 \mathrm{~g} / \mathrm{kg}$ lysine added diet resulted in the highest body weight at $42 \mathrm{~d}$ of age ( $2253 \mathrm{~g})$ and with no lysine supplementation performed the lowest body weight in the control birds (2163 g). A better performance in a height lysine is related to a higher amino acid availability to muscle growth and the better efficiency rate of protein and energy in transforming into tissue synthesis and accumulation (Nasr et al., 2011).

Responses of AA birds to an increment of lysine supplementation for BWG varied (Figure 1) whilst LN birds responded in a similar manner from hatching to $30 \mathrm{~d}$ of age ( Figure 2). The average growth rate was $50.6 \mathrm{~g} / \mathrm{d}$ and $47.5 \mathrm{~g} / \mathrm{d}$ and the highest responses were in $0.5 \mathrm{~g} / \mathrm{kg}$ lysine HCL $(52.4 \mathrm{~g} / \mathrm{d})$ for AA birds and $1.0 \mathrm{~g} / \mathrm{kg}$ lysine HCL (48.0 g/d) for LN birds respectively. The AA broilers were significantly more efficient than did LN broilers with FCR was 1.871 and 1.923 respectively. These are probably related to the differences in the ratio of synthesis and degradation of body proteins (Fatufe et al., 2004). The present findings are consistent with Praharaj et al. (2002), Sterling et al. (2006), and Rack et al. (2009) who observed differences in response to $\mathrm{CP}$ and limiting amino acids in different genotypes.

Feed intake increased linearly in response to the incremental dietary lysine (Table 2). This is similar to previous studies reported by some workers (Sterling et al., 2006; Aftab et al., 2007; Viola et al., 2009). However, this study also obtained at the highest feed intake did not increase the abdominal fat. These results corresponded with those of Hosseini et al. (2009) who observed an increase in feed intake of excess 
Table 2. Effect of Sex, Strain and Dietary Treatment on Body Weight Gain (g), Feed Intake (g), FCR and Live Body Weight (g) of Commercial Broilers from Hatching until 42 Days of Age

\begin{tabular}{|c|c|c|c|c|c|}
\hline Treatment & & Gain $(\mathrm{g})$ & Feed Intake (g) & FCR (g:g) & Live weight $(\mathrm{g})$ \\
\hline \multirow[t]{5}{*}{ Lysine HCL (g/kg) } & 0.0 & 2028 & 3774 & 1.862 & 2163 \\
\hline & 0.5 & 2046 & 3845 & 1.886 & 2196 \\
\hline & 1.0 & 2066 & 3977 & 1.928 & 2199 \\
\hline & 1.5 & 2069 & 3993 & 1.929 & 2210 \\
\hline & 2.0 & 2083 & 4005 & 1.938 & 2253 \\
\hline \multirow[t]{2}{*}{ Sex } & Male & $2140^{\mathrm{a}}$ & $4045^{\mathrm{a}}$ & 1.895 & $2245^{\mathrm{a}}$ \\
\hline & Female & $1974^{\mathrm{b}}$ & $3791^{b}$ & 1.923 & $2155^{b}$ \\
\hline \multirow[t]{2}{*}{ Genotype } & AA & 2083 & $3840^{b}$ & $1.871^{\mathrm{b}}$ & $2214^{\mathrm{a}}$ \\
\hline & $\mathrm{LN}$ & 2032 & $3996^{\mathrm{a}}$ & $1.947^{\mathrm{a}}$ & $2176^{\mathrm{b}}$ \\
\hline ANOVA & DF & \multicolumn{4}{|c|}{ Probabilities } \\
\hline Lysine & 4 & 0.9176 & 0.1091 & 0.4179 & 0.6390 \\
\hline Sex & 1 & 0.0002 & 0.0003 & 0.3414 & 0.0186 \\
\hline Genotype & 1 & 0.2170 & 0.0206 & 0.0001 & 0.3637 \\
\hline Lysine $x$ Sex & 4 & 0.7472 & 0.7325 & 0.4958 & 0.2040 \\
\hline Lysine $x$ Genotype & 4 & 0.2076 & 0.2156 & 0.5610 & 0.5788 \\
\hline Sex x Genotype & 1 & 0.3305 & 0.1804 & 0.9937 & 0.2359 \\
\hline Lysine x Sex x Genotype & 4 & 0.9958 & 0.5331 & 0.6853 & 0.0105 \\
\hline Error & 59 & & & & \\
\hline
\end{tabular}

a-b Values within comparison with different superscripts indicate significantly different $(\mathrm{P}<0.05)$

lysine diet was related to higher requirements for energy to support better metabolism of additional lysine.

Considerable research have reported that broilers fed low CP diet supplemented with essential amino acids, to some extent, could accurate growth depression (Hussein and $\mathrm{Al}$ Batshan, 1999; Sterling et al., 2006; AbdelMaksoud et al., 2010; Khan et al., 2011). Lysine was one of the essential amino acids that are very critical primarily in the commercial feed in the tropical regions where the ambient temperature have a contributable effect on feed intake. The low performance of the high temperature was because of the limited ability of chickens to release body heat (Gous, 1998; Ojano-Dirain and Waldroup, 2002). In warmer conditions $\left(32^{\circ} \mathrm{C}\right)$ compared to $22^{\circ} \mathrm{C}$, lysine would affect the metabolism of proteins (Tabiri et al., 1998; Temim et al., 2000), resulting to increasing the requirements of energy. In addition, at hot climate, high protein does not change the protein turnover (Temim et al., 2000). Low performance in high temperature was due to reduced feed intake (Hussein and Al-Batshan, 1999; Faria Filho et al., 2007) with a consequent effect was 
Table 3. The Influence of Lysine Level on Breast Meat, Abdominal Fat and Carcass (g) of Broiler Genotypes from Hatching to 42 Days of Age

\begin{tabular}{|c|c|c|c|c|}
\hline Treatments & & Breast Meat (g) & Abdominal Fat (g) & Carcass (g) \\
\hline \multirow[t]{5}{*}{ Lysine HCL (g/kg) } & 0.0 & 337.5 & 46.7 & $1563^{\mathrm{a}}$ \\
\hline & 0.5 & 337.9 & 45.3 & $1524^{\mathrm{a}}$ \\
\hline & 1.0 & 351.1 & 49.0 & $1570^{\mathrm{a}}$ \\
\hline & 1.5 & 332.0 & 48.6 & $1516^{\mathrm{b}}$ \\
\hline & 2.0 & 354.7 & 45.7 & $1643^{\mathrm{a}}$ \\
\hline \multirow[t]{2}{*}{ Sex } & Male & $358.1^{\mathrm{a}}$ & $46.9^{\mathrm{b}}$ & $1619^{\mathrm{a}}$ \\
\hline & Female & $327.7^{b}$ & $47.9^{\mathrm{a}}$ & $1485^{b}$ \\
\hline \multirow[t]{2}{*}{ Genotype } & AA & 339.2 & 46.1 & 1565 \\
\hline & $\mathrm{LN}$ & 346.2 & 48.8 & 1538 \\
\hline Lysine & 4 & 0.5595 & 0.7417 & 0.8848 \\
\hline Sex & 1 & 0.0015 & 0.0112 & 0.0008 \\
\hline Genotype & 1 & 0.5217 & 0.1131 & 0.5442 \\
\hline Lysine $\mathrm{x}$ Sex & 4 & 0.4748 & 0.6319 & 0.9170 \\
\hline Lysine x Genotype & 4 & 0.1169 & 0.2666 & 0.0430 \\
\hline Sex x Genotype & 1 & 0.0867 & 0.0502 & 0.0085 \\
\hline Lysine x Sex x Genotype & 4 & 0.3080 & 0.4959 & 0.5383 \\
\hline Error & 99 & & & \\
\hline Total & 118 & & & \\
\hline
\end{tabular}

a-b Values within comparison with different superscripts indicate significantly different $(\mathrm{P}<0.05)$

deficiency in other nutrient requirements particularly lysine intake.

Razuki et al. (2011) reported the differences between genotypes in BW to be genotype dependent. The differences between genotypes in their growth at high ambient temperature were related to their genetic potential for growth rate. For instance, BWG of Rose, Hubbard, Cobb and Lohmann from 29-49 d of age were $1032 \pm 15.89$, $1017 \pm 16.90$, and $1113 \pm 16.30$ and $1051 \pm 15.89 \mathrm{~g}$ at environmental temperature $35-36^{\circ} \mathrm{C}$. At the time of the study, the experiment was conducted in an open-sided house with ambient temperature can be categorized quite high with a range between $32-35^{\circ} \mathrm{C}$. This condition mainly affects in the control group with no lysine supplementation which showed the lowest total body weight gain than other groups. This is also supported by the data of lower total feed intake compared with the group receiving lysine supplementation (Table 2). When refer to the study of Temim et al. (2000), it was clear that at heat exposure changes specifically the requirements of some amino acids rather than protein requirements. Increasing utilization of the protein fraction of the diet may have caused an increase in the total heat increment metabolized (Rack et al., 2009). Therefore, improvement in weight gain with the use of low CP diet supplemented with lysine was more likely due to a reduction in heat increment produced by the metabolism of excess proteins (Saima et al., 2010). The low protein diet with ideal protein concept improved performance in heat exposure 
Table 4. Live Weight, Breast Meat and Abdominal Fat of Two Different Genotypes Fed Supplemented Lysine from 4 to 42 Days of Age with SEM*

\begin{tabular}{|c|c|c|c|c|c|c|c|c|}
\hline \multirow[b]{2}{*}{$\begin{array}{l}\text { Geno- } \\
\text { types }\end{array}$} & \multirow[b]{2}{*}{$\begin{array}{l}\text { Lysine } \\
\text { Supple- } \\
\text { mentation } \\
(\mathrm{g} / \mathrm{kg})\end{array}$} & \multirow[b]{2}{*}{$\mathrm{N}$} & \multicolumn{3}{|c|}{ Male } & \multicolumn{3}{|c|}{ Female } \\
\hline & & & $\begin{array}{l}\text { Live } \\
\text { weight } \\
\text { (kg) }\end{array}$ & $\begin{array}{c}\text { Breast (\% } \\
\text { of live } \\
\text { weight) }\end{array}$ & $\begin{array}{c}\text { Fat (\% of } \\
\text { live } \\
\text { weight) }\end{array}$ & $\begin{array}{c}\text { Live } \\
\text { weight } \\
(\mathrm{kg})\end{array}$ & $\begin{array}{c}\text { Breast (\% } \\
\text { of live } \\
\text { weight) }\end{array}$ & $\begin{array}{c}\text { Fat }(\% \text { of } \\
\text { live } \\
\text { weight })\end{array}$ \\
\hline AA & 0.0 & $12 *$ & $2.23 \pm 0.07$ & $14.86 \pm 1.53$ & $1.86 \pm 0.55$ & $1.98 \pm 0.16$ & $15.04 \pm 0.49$ & $2.47 \pm 0.60$ \\
\hline AA & 0.5 & 12 & $2.46 \pm 0.16$ & $15.27 \pm 0.79$ & $1.89 \pm 0.52$ & $1.99 \pm 0.07$ & $15.03 \pm 2.15$ & $2.04 \pm 0.46$ \\
\hline AA & 1.0 & 12 & $2.33 \pm 0.32$ & $16.45 \pm 1.97$ & $1.79 \pm 0.15$ & $2.18 \pm 0.25$ & $15.33 \pm 1.84$ & $2.24 \pm 0.60$ \\
\hline AA & 1.5 & 11 & $2.53 \pm 0.34$ & $14.58 \pm 1.08$ & $1.88 \pm 0.36$ & $1.99 \pm 0.16$ & $15.33 \pm 1.21$ & $2.61 \pm 0.74$ \\
\hline AA & 2.0 & 12 & $2.36 \pm 0.39$ & $15.52 \pm 1.59$ & $1.89 \pm 0.55$ & $2.27 \pm 0.42$ & $15.09 \pm 1.68$ & $2.22 \pm 0.70$ \\
\hline $\mathrm{LN}$ & 0.0 & 12 & $2.35 \pm 0.25$ & $15.64 \pm 1.02$ & $2.02 \pm 0.39$ & $2.28 \pm 0.29$ & $15.95 \pm 1.92$ & $2.18 \pm 0.41$ \\
\hline $\mathrm{LN}$ & 0.5 & 12 & $2.28 \pm 0.40$ & $15.49 \pm 1.80$ & $2.26 \pm 0.72$ & $2.06 \pm 0.29$ & $15.37 \pm 1.43$ & $2.02 \pm 0.22$ \\
\hline $\mathrm{LN}$ & 1.0 & 11 & $2.23 \pm 0.86$ & $15.56 \pm 0.77$ & $2.36 \pm 0.83$ & $2.05 \pm 0.18$ & $16.58 \pm 1.69$ & $2.62 \pm 0.57$ \\
\hline $\mathrm{LN}$ & 1.5 & 12 & $2.09 \pm 0.23$ & $15.06 \pm 1.03$ & $2.18 \pm 0.46$ & $2.12 \pm 0.12$ & $16.31 \pm 1.04$ & $2.04 \pm 0.36$ \\
\hline LN & 2.0 & 13 & $2.26 \pm 0.29$ & $16.90 \pm 0.01$ & $2.16 \pm 0.74$ & $2.04 \pm 0.08$ & $16.20 \pm 0.70$ & $2.55 \pm 0.48$ \\
\hline
\end{tabular}

$*$ SEM $=$ Standard Error Mean

broilers (Faria Filho et al., 2007). Thus, it is possible that low performance broilers reared under practical condition which is mostly raised in different environment, lysine supplementation could eliminate the detrimental effects of high ambient temperature. This suggests that environmental temperature should be taken into account in formulating a diet when broilers are raised in an open -sided house.

In regard to the effect of sex for all variables measured, this study showed significant differences $(\mathrm{P}<0.05)$ except for feed conversion (Table 2). Males have demonstrated a better ability to use the feed to be converted into body weight. Males genetically have slow feathering growth than females which influence the different needs and use of dietary protein. Samadi and Liebert (2006) estimated the genetic potential for daily $\mathrm{N}$ deposition in fast growing chickens. They reported that daily protein deposition is depending on age and sex. Males gain faster from post-hatching to $45 \mathrm{~d}$ of age than females. Daily protein deposition increase from 11 to $21 \mathrm{~g} / \mathrm{d}$ for males and 10 to $19 \mathrm{~g} / \mathrm{d}$ for females respectively. In addition, it was shown by the study of $\mathrm{Li}$ and Nolan (2002) that the daily protein synthesis and degradation rate for male broilers were higher than female broilers, suggesting that protein accretion rate in males was also higher than females. It is much clear that the need for lysine in males was higher than females.

\section{Genotypes and Carcass Parameters}

The results in Table 3 indicate that the 2.0 $\mathrm{g} / \mathrm{kg}$ lysine supplemented in a commercial standard diet improved the carcass weight with no significant effect in breast meat and abdominal fat. Genotypes by dietary lysine interaction were not significant for the carcass composition measured, but the response of chicks to increasing dietary lysine level improved breast meat yield and reduced abdominal fat for both genotypes. AA broilers were heavier for dietary lysine supplementation; however, LN broilers had higher breast yields. In addition, AA broilers were more efficient in lower lysine supplementation (1.0 g lysine $/ \mathrm{kg}$ diet) with the highest percentage of breast meat $(16.45 \pm 1.97 \mathrm{~g} / \mathrm{kg})$ and the lowest abdominal fat $(1.79 \pm 0.15 \mathrm{~g} / \mathrm{kg}$ ) (Table 4) or $383.36 \pm 70.72$ and $41.65 \pm 5.92 \mathrm{~g}$ respectively (data not shown). Whilst, LN broilers showed better response in $2.0 \mathrm{~g} / \mathrm{kg}$ lysine with the highest 


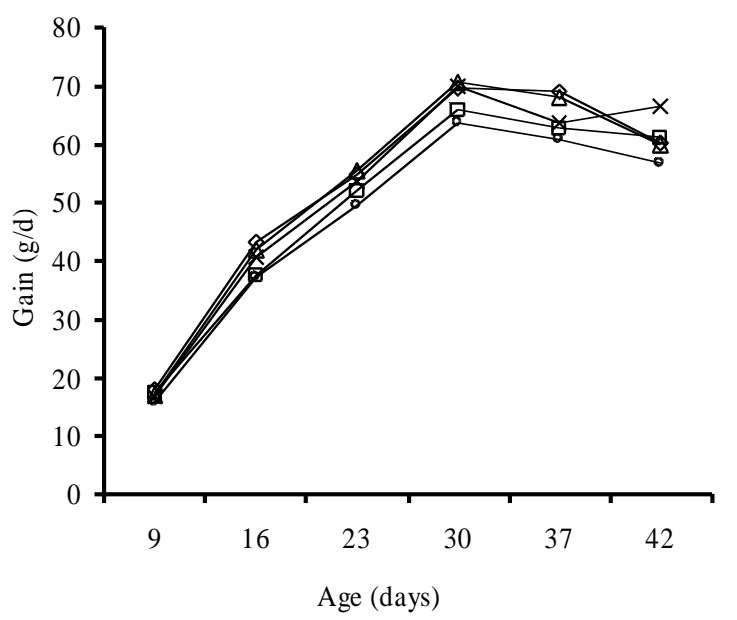

Figure 1. Gain (g/d) of Arbor Acres from 9 to 42 Day of Age at Different Lysine Supplementation (口:control; $\diamond: 0.5 ; \quad \Delta: 1.5 ; \quad \mathrm{x}: 1.5$ and $0: 2.0 \mathrm{~g} / \mathrm{kg}$ lysine mono-HCL)

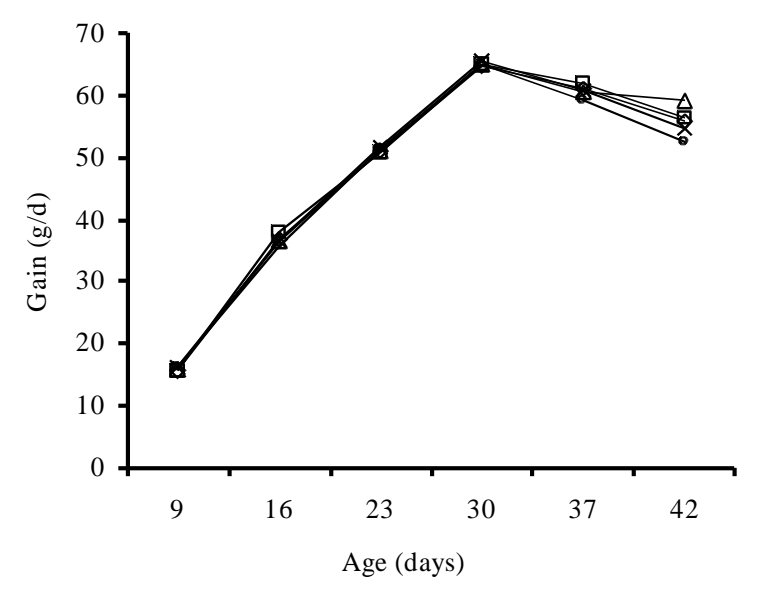

Figure 2. Gain (g/d) of Lohmann from 9 to 42 Day of Age at Different Lysine Supplementation ( $\square:$ control; $\quad \diamond: 0.5 ; \quad \Delta: 1.5 ; \quad \mathrm{x}: 1.5$ and $\odot: 2.0 \mathrm{~g} / \mathrm{kg}$ lysine mono-HCL)

percentage of breast meat $(16.90 \pm 0.01$ or $380.3 \pm 42.45 \mathrm{~g})$ and lower fat $(2.16 \pm 0.74$ or 48.76 $\pm 18.62 \mathrm{~g}$ ) (data not shown). The present findings are consistent with Sterling et al. (2006) and Alawumi and Fagbuaro (2011) who showed the differences between genotypes in BW and carcass traits to be genotype dependent.

It is interesting to note that the reduction in breast meat in males fed with a standard diet with no lysine was larger than females (Table 4). This indicates that males are more susceptible to low levels of dietary lysine in both genotypes and AA broilers require low level of dietary lysine. Hussein and Al-Batshan (1999) found that that there is interaction between temperature, sex, dietary protein and lysine breast meat. OjanoDirain and Waldroup (2002) also observed that increasing dietary lysine (from 1.03 to $1.16 \%$ ) of moderate heat-stressed $\left(26.7^{\circ} \mathrm{C}\right)$ from 3 to 6 week-old male broilers significantly increased breast meat (from 22.99 to $23.55 \%$ ) and reduced abdominal fat (0.832 to $0.663 \%)$.

In regard to effect of sex on carcass parameters, this present experiment showed that male broilers had higher value in carcass weight, breast weight and abdominal fat weight $(\mathrm{P}<0.05)$ than females. Although digestible lysine of the basal diet was not determined, this study was supported by the observations of Garcia et al. (2006), who reported differences in digestible lysine requirement for males and females for breast meat deposition. The highest breast meat $(379.4 \pm 15.5 \mathrm{~g})$ and body weight gain $(1591.0 \pm 27$ g) of male broilers from 21 to 42 days of age due to lysine supplementation have been reported by Ghahri et al. (2010). These authors found the lysine requirement averaged $1.097 \pm 0.073 \%$ and $0.907 \pm 0.0046 \%$ with linear-broken line estimation at $22 \%$ and $18 \%$ crude protein for BM and BWG respectively. Thus, breast meat yield again was better in diet supplemented lysine, and the implication of this study is that lysine addition in a conventional standard diet is necessary and separated feeding system should also be considered to achieve the optimal performance.

\section{CONCLUSION}

The results of the present study demonstrated that different genotype broilers grown under conventional management practice in uncontrolled environment required different nutritional need. Lysine supplementation is more desirable to support the actual growth potential and breast meat yield of fast growing broilers particularly in which a conventional standard commercial diet was used. Low performance of particular genotypes was due to their nutritional requirement was not completely fulfilled.

\section{ACKNOWLEDGMENTS}

The authors wish to thank the technical staff 
of the teaching farm particularly Kasri for rearing and slaughtering the animals, and the students for carcass dissections. Data presented in this paper was collected at teaching farm of Faculty of Animal Science-Mataram University and the funding was provided by TPSDP project-ADB Loan 1792 INO.

\section{REFERENCES}

Abdel-Maksoud, A., F. Yan, S. Cerrate, C. Coto, Z. Wang and P. W. Waldroup. 2010. Effect of dietary crude protein, lysine level and amino acid balance on performance of broilers 0 to 18 days of age. Int. J. Poult. Sci. 9(1):21-27.

Aftab, U., M. Ashraf, A. S. Mumtaz and Z. Jiang. 2007. Lysine requirement of broiler chickens fed low-density diets under tropical conditions. Asian-Aust. J. Anim. Sci. 20(6): 939-943

Alawumi, S. O. and S. S. Fagbuaro. 2011. Productive performance of three commercial genotypes reared in the derived savannah zone of Nigeria. Int. J. Agri. Res. 6(11):798804. DOI: 10.3923/ijar.2011.798.804

Bartov, I. and I. Plavnik. 1998. Moderate excess of dietary protein increases breast meat yield of broiler chicks. Poult. Sci. 77: 680-688

Cherry, J., P. B. Siegel and W. L. Beane. 1978. Genetic-nutritional relationship characteristic of broiler chickens. Poult. Sci. 57:14821487.

Dozier, W. A., III, A. Corzo , M. T. Kidd, P. B. Tillman and S. L. Branton. 2009.

Digestible lysine requirements of male and female broilers from fourteen to twenty-eight days of age. Poult. Sci. 88:1676-1682. doi: 10.3382/ps.2008-00539.

Dozier, W. A., III , A. Corzo , M. T. Kidd , P. B. Tillman , J. P. McMurtry and S. L. Branton. 2010. Digestible lysine requirements of male broilers from 28 to 42 days of age. Poult. Sci. 89:2173-2182 doi: 10.3382/ps.201000710.

Faria Filho, D.E. , D. M. B. Campos, K. A. Alfonso-Torres, B. S. Vieira, P. S. Rosa, A. M. Vaz, M. Macari and R. L. Furlan. 2007. Protein levels for heat-exposed broilers: Performance, nutrients digestibility, and energy and protein metabolism. Int. J. Poult. Sci. 6 (3):187-194

Fatufe, A. A. R. Timmler, and M. Rodehutscord. 2004. Response to lysine intake in composition of body weight gain and efficiency of lysine utilization of growing male chickens from two genotypes. Poult. Sci. 83:1314-1324

Garcia, A. R., A. B. Batal, and D. H. Baker. 2006. Variations in the digestible lysine requirement of broiler chickens due to sex, performance parameters, rearing environment, and processing yield characteristics. Poult. Sci. 85:498-504

Ghahri, H., R. Gaykani and T. Toloie. 2010. Effect of dietary crude protein level on performance and lysine requirements of male broiler chickens. Afr. J. Agric. Res. 5(11):1228-1234

Gous, R. M. 1998. Making progress in the nutrition of broilers. Poult. Sci. 7:111-117.

Greenwood, M. W., K. R. Cramer, R. S. Beyer, P. M. Clark and K. C. Behnke. 2005. Influence of feed form on estimated digestible lysine needs of male broilers from sixteen to thirty days of age. J. Appl. Poult. Res. 14:130-135

Harms, R. H. and G. B. Russell. 1995. A reevaluation of the protein and lysine requirement for broiler breeder hens. Poult. Sci. 74: 581-585.

Hosseini, S. M., S. M. Akbary, N. Maheri-Sis and A. Mirzaei-Aghsaghali. 2009. The effect of using excess lysine on the performance and slaughter characteristics of broiler chickens. Res. J. Biol. Sci. 4(2):143-147.

Hussein, E. O. S. and H. A. Al-Batshan. 1999. Performance and carcass composition of broilers under heat stress : II. The effect of dietary lysine. Asian-Aust. J. Anim. Sci. 12 (6): 923-931.

Indarsih, B. and R. A. E. Pym. 2010. The effect of genotype on response in body composition to variation in dietary protein: energy ratios. J. Indonesian Trop. Anim. Agric. 35(2):102108.

Kerr, B. J., M. T. Kidd, K. M. Halpin, G. W. McWard and C. L. Quarles. 1999. Lysine level increase level performance in male broilers. J. Appl. Poult. Res. 8:381-390

Khan, S. A., N. Ujjan, G. Ahmed, M. I. Rind, S. A. Fazlani, S. Faraz, S. Ahmed and M. Asif. 2011. Effect of low protein diet supplemented with or without amino acids on the production of broiler. Afric. J. Biotechnol . 10 (49):10058-10065

Kidd, M. T., B. J. Kerr. J. P. Allard, S. K. Rao and J. T. Halley. 2000. Limiting amino acid responses in commercial broilers. J. Appl. Poult. Res. 9: 223-233. 
Labadan, Jr. M.C., K. N. Hsu, and R. E. Austic. 2001. Lysine and arginine requirements of broiler chickens at two to three-week intervals to eight weeks of age. Poult. Sci. 80:599-606.

Leclercq, B., A. M. Chagneau, T. Cochard, S. Hamzaoui, and M. Larbier. 1993.Comparative utilization of sulfurcontaining amino acids by genetically lean or fat chickens. Br. Poult. Sci. 34: 383-391.

Leeson, S. 2000. Nutrition and quality of the broiler carcass. www.gov.on.ca/ livestock/poultry/facts/carcass.html

Lehmann, D., M. Pack, and H. Jeroch. 1996. Responses of growing and finishing turkey Toms to dietary lysine. Poult. Sci. 75:711718.

Li, L. and J. V. Nolan. 2002. Efficiency of protein utilization in male and female broiler chickens. Proc. Aust. Poult. Sci. Sym. 14:175-178.

Mehri, M., H. Nassiri-Moghaddam, $\quad H$. Kermanshahi and M. Danesh-Mesgaran. 2010. Digestible lysine requirements of strain-run broiler chickens from fifteen to twenty-eight days of age. J. Anim. Vet. Adv. 9(17):2321-2324

Moran, Jr. E. T. and S. F. Bilgili. 1990. Processing losses, carcass quality, and meat yields of broiler chickens receiving diets marginally deficient to adequate in lysine prior to marketing. Poult. Sci. 69:702-710

Moran, Jr. E. T. 1994. Response of broiler strains differing in body fat to inadequate methionine: Live performance and processing yields. Poult. Sci. 73:1116-1126

Nasr, J. and F. Kheiri. 2011. Increasing amino acids density improves broiler live weight. Int. J. Poult. Sci. 10(7):523-526.

Nasr, J., F. Kheiri, A. Solati, A. Hajibabaei and M. Senemari. 2011. The efficiency of energy and protein of broiler chickens fed on diets with different lysine concentration. J. Anim. Vet. Adv. 10(18):2394-2397

National Research Council. 1971. Nutrient Requirements of Poultry. Sixth Edition. National Academy of Sciences, National Research Council, Washington, DC.

National Research Council. 1987. Predicting feed intake of food-producing Animals. National Academy Press, Washington, DC.

National Research Council. 1994. Nutrient Requirements of Poultry Ninth Revised Edition. National Academy Press,
Washington, DC.

Ojano-Dirain, C. P. and P. W. Waldroup. 2002. Protein and amino acid needs of broilers in warm weather: A review. Int. J. Poult. Sci. 1(4):40-46.

Praharaj, N. K., M. R. Reddy, A. K. Panda, S. V. Rama Rao and R. P. Sharma. 2002. Genotype by dietary lysine interaction for growth and response to sheep red blood cells and Escherichia coli inoculation in commercial broiler chicks. Asian-Aust. J. Anim. Sci. 15(8):1170-1177

Quentin, M., I. Bouvarel and M. Picard. 2005. Effects of crude protein and lysine contents of the diet on growth and body composition of slow-growing commercial broilers from 42 to 77 days of age. Anim. Res. 54. 113122. doi: 10.1051/animres:2005010

Rack, A. 1., K. G. S. Lilly, K. R. Beaman, C. K. Gehring, and J. S. Moritz . 2009. The effect of genotype, choice feeding, and season on organically reared broilers fed diets devoid of synthetic methionine. J. Appl. Poult. Res. 18 :54-65 doi: 10.3382/japr.2008-00053

Razuki, W. M., S. A. Mukhlis, F. H. Jasim and R. F. Hamad. 2011. Productive performance of four commercial broiler genotypes reared under high ambient temperature. Int. J. Poult. Sci. 10 (2):87-92.

Rezaei, M., H. Nassiri Moghaddam, J. Pour Reza and H. Kermanshahi. 2004. The effects of dietary protein and lysine levels on broiler performance, carcass characteristics and $\mathrm{N}$ excretion. Int. J. Poult. Sci. 3(2):148-152.

SAS Institute Inc. 1996. SAS User's Guide: Statistics. Version 6.12. SAS Institute Inc., Cary, NC.

Saima, M., Z. U. Khan, M. A. Jabbar, A. Mehmud, M. M. Abbas and A. Mahmood. 2010. Effect of lysine supplementation in low protein diets on the performance of growing broilers. Pakistan Vet. J. 30 (1):1720.

Samadi and F. Liebert. 2006. Estimation of nitrogen maintenance requirements and potential for nitrogen deposition in fastgrowing chickens depending on age and sex. Poult. Sci. 85:1421-1429.

Steel, R. G. D. and J. H. Torrie. 1980. Principles and Procedures of Statistics. A biometrical approach. 2nd Ed., McGraw Hill Inter. Book Co. Tokyo, Japan.

Sterling, K. G., G. M. Pesti, and R. I. Bakalli. 2006. Performance of different broiler 
genotypes fed diets with varying levels of dietary crude protein and lysine. Poult. Sci. 85:1045-1054.

Tabiri, H., K. Sato, K. Takahashi, M.Toyomizu, and Y. Akiba. 1998. Effect of heat stress and dietary tryptophan on performance and plasma amino acids concentration of broiler chickens. Proc. $6^{\text {th }}$ Asian Pacific Poultry Congress. Nagoya, Japan, p. 378-379.

Temim, S., A. M. Chagneau, S. Guillaumin, J.
Michel, R. Peresson, and S. Tesseraud. 2000. Does excess dietary protein improve growth performance and carcass characteristics in heat-exposed chickens?. Poult. Sci.79:312317.

Viola, TH., A de M. Kessler, AML. Ribeiro, ICM da Silva and R. Krás. 2009. The influence of crude protein level in the basal diet on the determination of lysine requirements for broiler performance and part yields. Brazilian J. Poult. Sci. 11 (3):155-160. 